\title{
Angiogenesis and vascular endothelial growth factor expression in the equine corpus luteum
}

\author{
M. O. Al-zi'abi ${ }^{1}$, E. D. Watson ${ }^{1 *}$ and H. M. Fraser ${ }^{2}$ \\ ${ }^{1}$ Department of Veterinary Clinical Studies, University of Edinburgh, Easter Bush, Midlothian EH25 9RG, \\ UK; and ${ }^{2}$ MRC Human Reproductive Sciences Unit, The University of Edinburgh Academic Centre, \\ 49 Little France Crescent, Edinburgh EH16 4SB, UK
}

\begin{abstract}
Precise pharmacological control of the corpus luteum is important in the manipulation of the oestrous cycle in mares. Angiogenesis plays a key role in the growth and regression of the corpus luteum; therefore, influencing the vasculature of the corpus luteum may offer a novel method for controlling its lifespan. In the present study, changes in angiogenesis and vascular expression of endothelial growth factor (VEGF) were evaluated throughout the luteal phase and after $\mathbf{P G F}_{2 \alpha}$-induced luteolysis. Corpora lutea were collected from mares in the early luteal phase (days 3-4), mid-luteal phase (day 10), early regression (day 14), late regression (day 17), and at 12 and $36 \mathrm{~h}$ after administration of $\mathrm{PGF}_{2 \alpha}$ on day 10 of the oestrous cycle. Immunohistochemistry was used to localize Von Willebrand factor and Ki67 in endothelial and proliferating cells, respectively. VEGF $m$ RNA and protein were localized
\end{abstract}

by in situ hybridization and immunohistochemistry. The proliferation index of endothelial cells was intense in the early luteal phase. The early and mid-luteal phases were characterized by a dense network of capillaries. The microvasculature started to regress by day 14 . After administration of $\mathbf{P G F}_{2 \alpha}$, vasodilation was observed after $12 \mathrm{~h}$, but after $36 \mathrm{~h}$, luteal degeneration was accompanied by a significant decrease in vascularity. VEGF mRNA and protein were expressed mainly in the luteal cells during the early and mid-luteal phases and expression declined at early regression (day 14). However, immunostaining for VEGF protein was high in late luteal regression (day 17) and $36 \mathrm{~h}$ after $\mathrm{PGF}_{2 \alpha}$ administration. These findings indicate a close temporal association between VEGF expression and angiogenesis in the equine corpus luteum during its functional lifespan.

\section{Introduction}

The corpus luteum undergoes extensive cellular proliferation and differentiation during luteinization and involutes rapidly at luteolysis. These changes involve intense growth and regression of microvessels (Reynolds et al., 1992; Zheng et al., 1993). Angiogenesis is essential for normal luteal function, and inhibition of angiogenesis is associated with functional luteal regression (Fraser et al., 2000). Pharmacological manipulation of luteolysis is a key element in oestrous cycle control in clinical equine reproduction. Currently, prostaglandin $\mathrm{F}_{2 \alpha}\left(\mathrm{PGF}_{2 \alpha}\right)$ can be administered from day 6 of the oestrous cycle onwards to initiate luteolysis (Oxender et al., 1975), but there is no treatment that can induce luteolysis during the entire luteal phase. The process of angiogenesis has not been studied in the equine corpus luteum, but pharmacological control of angiogenesis could offer an alternative approach in shortening the oestrous cycle.

*Correspondence

Email: elaine.watson@ed.ac.uk
Studies in ruminants have shown that the corpus luteum is one of the most highly vascularized tissues in the body (Bruce and Moor, 1976). Quantitative studies in the ovine corpus luteum have revealed that in the early luteal phase, endothelial cells constitute approximately $85 \%$ of proliferating cells and represent $>50 \%$ of the cells present in the mature corpus luteum (Reynolds et al., 1994). Luteolysis in ruminants may be associated with changes in the vasculature of the corpus luteum as there is a decrease in luteal vascularity in the late luteal phase (Zheng et al., 1993; Reynolds and Redmer, 1998), and this may be mediated by PGF $_{2 \alpha}$ (Nett et al., 1976; Niswender et al., 1976).

Angiogenesis in the corpus luteum is regulated by a number of growth factors (Fraser and Lunn, 2000). There is growing evidence that vascular endothelial growth factor (VEGF) is the main angiogenic factor in the corpus luteum (Reynolds and Redmer, 1998; Fraser et al., 2000; Sugino et al., 2000; Kashida et al., 2001), and VEGF mRNA and protein have been found in the corpus luteum of several species (Goede et al., 1998; Hazzard et al., 2000; Wulff et al., 2000). Although VEGF may be induced by hypoxia in most ischaemic tissues, it is 
probably regulated more closely by $\mathrm{LH}$ in the corpus luteum (Neulen et al., 1998; Dickson and Fraser, 2000).

In the present study, the pattern of endothelial cell proliferation throughout the luteal phase of the oestrous cycle and after induced luteal regression was investigated. VEGF mRNA and protein were localized throughout the luteal phase to establish whether VEGF is temporally associated with angiogenesis in the equine corpus luteum.

\section{Materials and Methods}

\section{Animals and tissue collection}

Pony mares of mixed breeding, aged 4-12 years and $250-450 \mathrm{~kg}$ body weight, were used. The ovaries of the mares were examined daily during oestrus by transrectal ultrasonography to determine the day of ovulation (day 0 ). The ovary containing the corpus luteum was removed by a colpotomy incision after appropriate sedation and analgesia (Lawler et al., 1999). Corpora lutea were obtained in the early luteal phase, days $3-4(n=4)$; mid-luteal phase, day $10(n=5)$; early regression, day $14(n=4)$; late regression, day $17(n=4) ;$ and at 12 and $36 \mathrm{~h}$ ( $n=3$ each) after i.m. administration of the $\mathrm{PGF}_{2 \alpha}$ analogue, cloprostenol (Estrumate, $263 \mu \mathrm{g} 500 \mathrm{~kg}^{-1}$, Schering-Plough Animal Health, Middlesex) on day 10 of the oestrous cycle. In an earlier study, it was shown that corpora lutea collected from mares $12 \mathrm{~h}$ after $\mathrm{PGF}_{2 \alpha}$ administration had cellular changes comparable to those seen during early natural regression (day 14), whereas corpora lutea collected at $36 \mathrm{~h}$ after $\mathrm{PGF}_{2 \alpha}$ treatment showed advanced degenerative changes similar to those observed during late natural regression (day 17$)$ (Al-zi'abi et al., 2002).

The ovaries were transported to the laboratory on ice immediately after surgical removal. The corpus luteum was enucleated from the ovary and dissected free of connective tissue. Tissue samples were fixed in $10 \%$ $(\mathrm{v} / \mathrm{v})$ neutral phosphate buffered formalin $(\mathrm{pH} 7.0)$ for $24 \mathrm{~h}$ at room temperature and then embedded in paraffin wax. Serial sections of $4 \mu \mathrm{m}$ were mounted on to glass microscope slides coated with poly-L-lysine (Sigma, Poole). This study was performed under the approval of the University of Edinburgh Ethical Review Committee and the project licence obtained under the Home Office Animals (Scientific Procedures) Act 1986.

\section{Immunohistochemistry}

The endothelial cells were identified by Von Willebrand factor (vWF) antigen and cell proliferation by Ki67 as described by Rodger et al. (1997), with slight modifications. The sections were treated with $0.1 \%$ $(\mathrm{w} / \mathrm{v})$ trypsin for $45 \mathrm{~min}$ at $37^{\circ} \mathrm{C}$ and incubated with rabbit anti-human vWF (Dako, High Wycombe) at a dilution of 1:250 for $90 \mathrm{~min}$ at room temperature. For
Ki67, sections were exposed to three $\times 10$ min cycles of microwave irradiation at $700 \mathrm{~W}$ in citrate buffer (0.01 moll-1, $\mathrm{pH}$ 6.0). The sections were incubated with a monoclonal antibody to the nuclear non-histone antigen, Ki67 (Novocastra, Peterborough) diluted to 1:40 for $3 \mathrm{~h}$ at $37^{\circ} \mathrm{C}$. For VEGF, sections were incubated with rabbit anti-VEGF (Santa Cruz Biotechnology, CA), diluted to $1: 200$ in PBS, for $120 \mathrm{~min}$ at room temperature or overnight at $4{ }^{\circ} \mathrm{C}$. Activated macrophages were detected using MAC 387 as the primary antibody (Dako). The sections were treated with $0.1 \%$ trypsin for $20 \mathrm{~min}$ and then incubated with primary antibody diluted to $1: 200$ for $60 \mathrm{~min}$. Negative control sections were incubated with $2 \%(\mathrm{v} / \mathrm{v})$ normal rabbit serum for $\mathrm{VWF}$ and VEGF or $2 \%(\mathrm{v} / \mathrm{v})$ normal mouse serum for $\mathrm{Ki} 67$ and MAC 387. Sections were visualized with $0.05 \%(\mathrm{w} / \mathrm{v}) 3,3^{\prime}$ diaminobenzidine containing $0.01 \%(\mathrm{v} / \mathrm{v}) \mathrm{H}_{2} \mathrm{O}_{2}$ (Sigma, Poole) and counterstained with haematoxylin.

\section{In situ hybridization for VEGF $m R N A$}

The method used for in situ hybridization was as described by Wulff et al. (2000) with slight modifications. In brief, complementary RNA probes for human VEGF were used. Sense and antisense probes were prepared using an RNA transcription kit (Ambion Inc., Austin, TX) and labelled with $\left[{ }^{35} \mathrm{~S}\right]$ UTP (NEN Life Science Products, Boston, MA). The sections were treated with $0.1 \mathrm{mmol}$ $\mathrm{HCl} \mathrm{I}{ }^{-1}$ and then digested in proteinase $\mathrm{K}\left(5 \mathrm{mg} \mathrm{ml}^{-1}\right.$, Sigma) for $30 \mathrm{~min}$ at $37^{\circ} \mathrm{C}$. A prehybridization step was carried out by incubation in prehybridization buffer containing $50 \%(\mathrm{v} / \mathrm{v})$ formamide, $4 \times$ standard saline citrate, $1 \times$ Denhardt's, $125 \mathrm{mg}$ salmon testis DNA ml ${ }^{-1}, 125 \mathrm{mg}$ yeast transfer RNA ml-1 and $10 \mathrm{mmol}$ dithiothreitol I-1 at $55^{\circ} \mathrm{C}$ in a moist chamber for $2 \mathrm{~h}$. Hybridization was performed in a moist chamber overnight at $55^{\circ} \mathrm{C}$. The hybridization buffer was similar to the prehybridization buffer, but contained $10 \%(\mathrm{w} / \mathrm{v})$ dextran sulphate. Two sections per slide were exposed to the antisense and sense sequences. Dry slides were dipped into Ilford G5 liquid emulsion (Ilford Imaging, Mobberly), exposed for 4.5 weeks at $4{ }^{\circ} \mathrm{C}$, and subsequently developed (Kodak D19 Developer, Eastman Kodak Co., Rochester, NY) and fixed (Kodak GBS). All slides were counterstained with haematoxylin. For light field photography, the coverslips were removed and the sections stained with haematoxylin-eosin.

\section{Quantification methods}

Microvessels. Microvessels were quantified in two ways: (i) density of blood vessels, to estimate the proportion of luteal tissue occupied by blood vessels and (ii) the area of vWF immunostaining. The density of the microvessels (\%) was calculated by examining sections at $\times 400$ magnification. An eyepiece grid was 

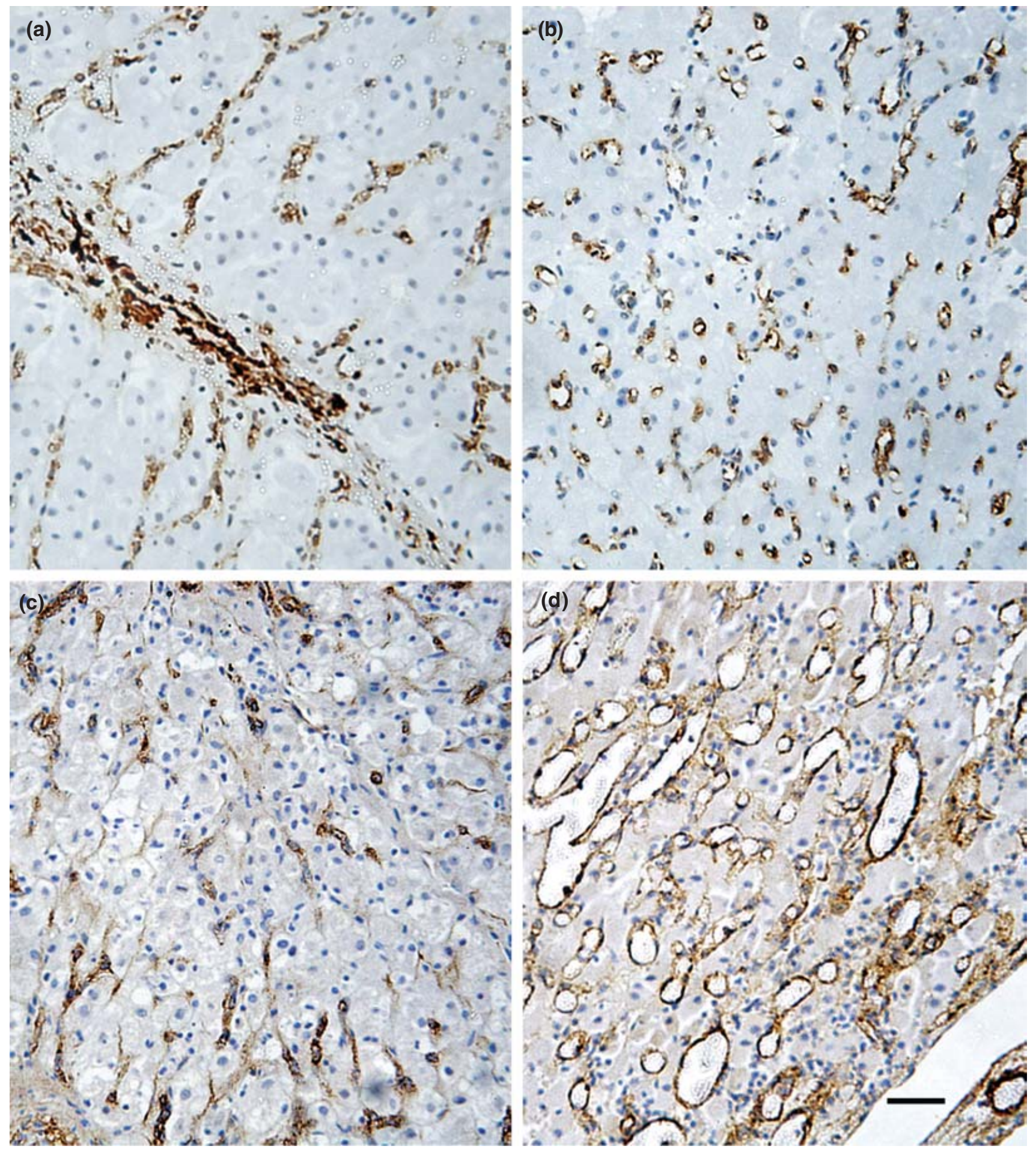

Fig. 1. Von Willebrand factor (vWF) immunostaining in the equine corpus luteum during (a) the early luteal phase, (b) the midluteal phase, (c) late regression and (d) $12 \mathrm{~h}$ after prostaglandin $\mathrm{F}_{2 \alpha}\left(\mathrm{PGF}_{2 \alpha}\right)$ administration. Endothelial cells and microvessels show positive immunostaining. Note intense VWF immunostaining during the early and mid-luteal phase, and reduction in vascularity in late regression. In (d) note vasodilation in the microvessels. Scale bar represents $50 \mu \mathrm{m}$.

used which covered an area of $0.063 \mathrm{~mm}^{2}(25 \mu \mathrm{m} \times$ $25 \mu \mathrm{m})$. Regions from the inner, middle and outer areas of the sections were selected randomly. Each point of the grid superimposed on positive immunostaining or on capillary lumina was counted and the total number of points was divided by the total number superimposed 


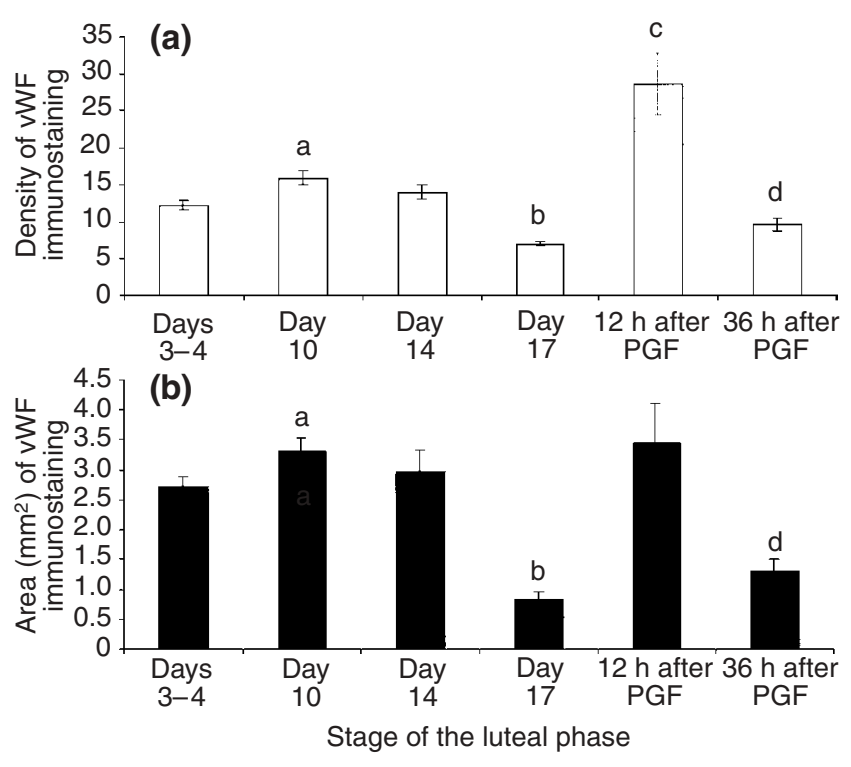

Fig. 2. (a) Density of Von Willebrand factor (vWF) immunostaining and (b) the area of VWF immunostaining in the equine corpus luteum throughout the early luteal phase, days 3-4 $(n=4)$; midluteal phase, day $10(n=5)$; early regression phase, day $14(n=4)$; late regression phase, day $17(n=4)$; and 12 and $36 \mathrm{~h}(n=3$ each) after i.m. administration of the prostaglandin $F_{2 \alpha}\left(P F_{2 \alpha}\right)$ analogue. The density for each stage of the luteal phase was expressed as the percentage mean \pm SEM, whereas the area of $\checkmark W F$ immunostaining was expressed as mean \pm SEM per unit area. a Value significantly $(P<0.05)$ higher than early luteal phase; ${ }^{b}$ value significantly $(P<0.01)$ lower than mid-luteal phase and early regression; ${ }^{\mathrm{C}}$ value significantly $(P<0.01)$ higher than all other groups; ${ }^{\mathrm{d}}$ value significantly $(P<0.01)$ lower than mid-luteal phase.

on luteal cells and the remainder of the luteal tissue $\times 100 \%$ (Ferrara et al., 1998; Gaytan et al., 1999). The area of vWF immunostaining was calculated using the Quantimet Image Processing and Analysis System 500 (Leica, Cambridge). The system was optimized for each individual section on the basis of the density of the stain. The area used in this system was calibrated at $\times 200$ magnification. Quantification was performed using unbiased counting rules (Gundersen et al., 1988). Single or clusters of endothelial cells were considered to be individual vessels. The density of the microvessels was expressed as a percentage mean \pm SEM, whereas the area of $v W F$ was expressed as mean \pm SEM.

Proliferation index. Fields were examined at $\times 400$ magnification. The number of Ki67-labelled nuclei and the total number of nuclei were counted. Two sections per animal and four fields per section were counted. The proliferation index was determined by the number of Ki67-labelled nuclei divided by the total number of nuclei $\times 100$ and expressed as a percentage mean \pm SEM. The types of cell immunostained for Ki67 were identified using the following classifications: endothelial cells were elongated with a long axis of about
4-8 $\mu \mathrm{m}$ and had little cytoplasm; luteal cells were large, round to vesicular shaped cells of $20-40 \mu \mathrm{m}$ in diameter, and contained large spherical to vesicular nuclei of $10-15 \mu \mathrm{m}$ in diameter. Cells that stained positive for Ki67 that did not fit the criteria described for endothelial cells or luteal cells were considered to be other types of cell, usually leucocytes or fibroblasts. Lymphoctyes were identified as approximately $10 \mu \mathrm{m}$ in diameter with round nuclei and scant cytoplasm. Plasma cells had abundant cytoplasm with an eccentric nucleus containing characteristic cartwheel chromatin. Neutrophils were identified by their segmented nucleus and neutrophilic cytoplasm. Fibroblasts were elongated with a long axis of about 2-6 $\mu \mathrm{m}$. They had little cytoplasm and were present in trabecular connective tissue. Different types of cell were expressed as mean \pm SEM per field.

VEGF $m R N A$. Grain density for VEGF mRNA was evaluated by scoring $(+++)$ for intense expression, $(++)$ for moderate expression, $(+)$ for low expression and $(+/-)$ for very weak expression.

Percentage area of VEGF immunostaining. The Quantimet image analysis system was used to calculate the percentage area of the immunostaining (area of the immunostaining divided by the total area measured $\times 100$ ). Areas were analysed at $\times 200$ magnification using two sections from each animal and four fields per section. The results were expressed as percentage mean \pm SEM per unit area.

MAC 387-positive cells. Positive cells in the cavity of the corpora lutea were counted at $\times 400$ magnification and expressed as mean \pm SEM per field.

\section{Statistical analysis}

The differences in corpora lutea collected at the early and mid-luteal phases, and early and late regression were analysed by one-way ANOVA using stage of the luteal phase as the between-subject variable. Data from untreated corpora lutea collected at the early and mid-luteal phases, and early and late regression were compared with corpora lutea after induced regression using a one-way ANOVA with treatment as the betweensubject variable. The data were subjected to Tukey's test of multicomparison among means. The results were considered to be significantly different when $P<0.05$.

\section{Results}

\section{$\checkmark W F$ immunostaining}

VWF immunostaining was localized to endothelial cells of microvessels and capillaries (Fig. 1). After ovulation, sprouting endothelial cells invaded the cavity of the corpus haemorrhagicum and began to form a 
(a)

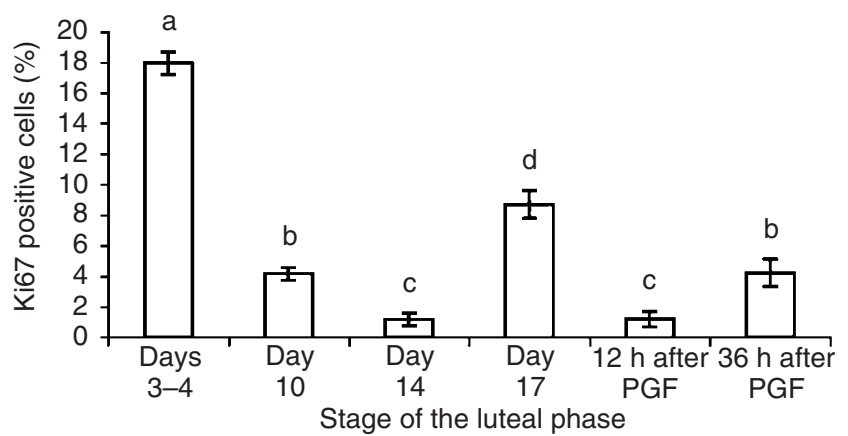

(c)

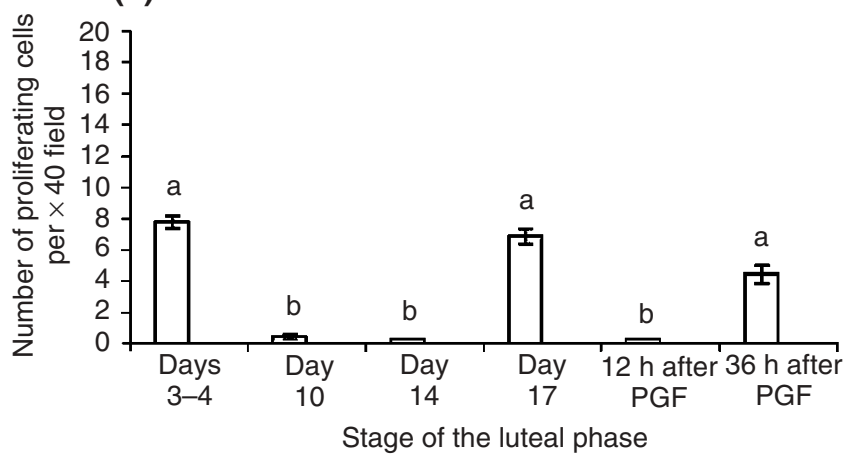

(b)

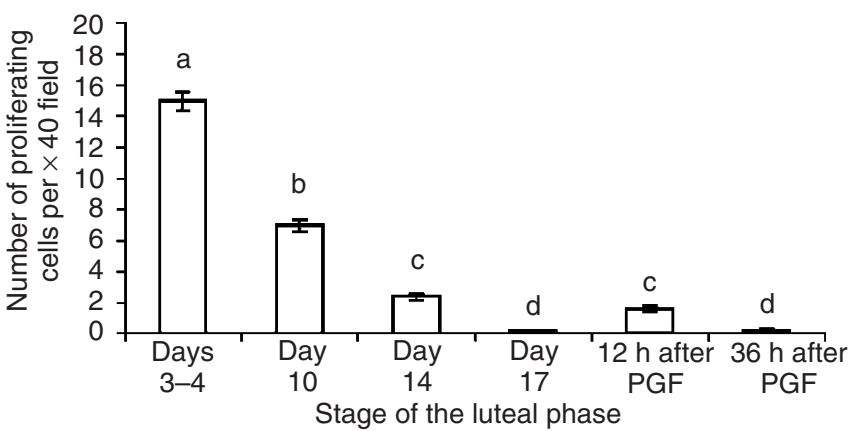

(d)

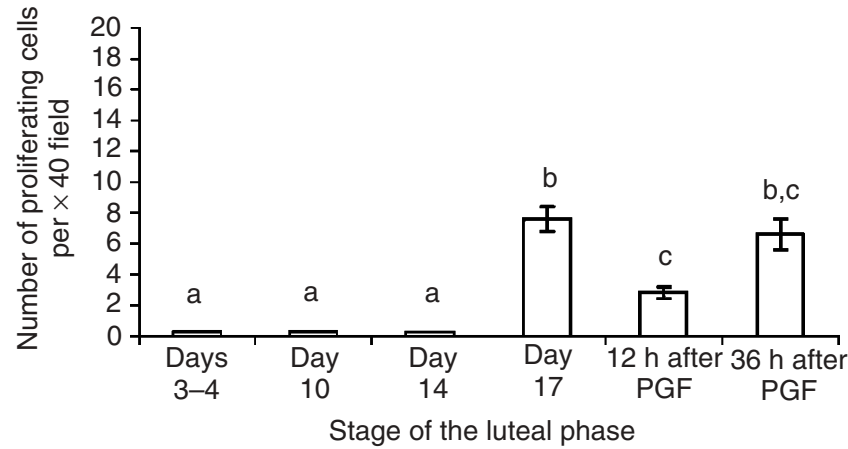

Fig. 3. Ki67 immunopositive cells ((a) proliferation index; (b) endothelial cells; (c) luteal cells; (d) other cells) in proliferating cells in the equine corpus luteum throughout the early luteal phase, days 3-4 $(n=4)$; mid-luteal phase, day $10(n=5)$; early regression, day $14(n=$ 4); late regression, day $17(n=4)$; and 12 and $36 \mathrm{~h}$ after i.m. administration of prostaglandin $\mathrm{F}_{2 \alpha}\left(\mathrm{PGF}_{2 \alpha}\right)(n=3$ each) analogue. Columns with different superscripts are significantly different $(P<0.05)$.

vascular bed between the luteal cells (Fig. 1a). The midluteal phase was characterized by a dense network of fully differentiated capillaries (Fig. 1b), and the density of the microvessels and the area of VWF immunostaining were significantly greater $(P<0.05)$ than in the early luteal phase (Fig. 2). During early regression, there was a slight decrease in the area and density of the microvessels. By late regression (day 17), the extensive vascular network of the mid-luteal phase had regressed (Fig. 1c). This regression resulted in a marked decrease $(P<$ $0.01)$ in microvessel density and area of VWF immunostaining. At $12 \mathrm{~h}$ after $\mathrm{PGF}_{2 \alpha}$ administration, microvessels underwent vasodilation (Fig. 1d), resulting in a significant increase in vessel density $(P<0.01)$. However, by $36 \mathrm{~h}$, vasodilation was no longer apparent. At this time there was a sharp decline in the density of the microvessels and the area of $\mathrm{VWF}$ immunostaining $(P<0.01)$ compared with at $12 \mathrm{~h}$ after $\mathrm{PGF}_{2 \alpha}$ administration. No immunostaining was present in negative control sections.

\section{Ki67 immunostaining}

Ki67 immunostaining was observed in all sections examined. The proliferation index changed throughout the oestrous cycle and after $\mathrm{PGF}_{2 \alpha}$-induced luteolysis (Fig. 3); the highest proliferation index was in the early luteal phase; the proliferation index declined by $>70 \%$ in the mid-luteal phase and early regression phase $(P<0.01)$. During late regression and at $36 \mathrm{~h}$ after $\mathrm{PGF}_{2 \alpha}$ administration, a significant increase in the proliferation index was observed $(P<0.05)$ compared with early regression and at $12 \mathrm{~h}$ after $\mathrm{PGF}_{2 \alpha}$ administration. Endothelial cells showed the highest proliferation rate during the early luteal phase (Figs $3 b$ and $4 a, b$ ); by the midluteal phase (Fig. $4 \mathrm{~b}$ ) and early regression (both natural and induced; Fig. 4c,e), the number of endothelial cells that stained positively for Ki67 decreased significantly $(P<0.01$; Fig. 3b). During natural and induced regression, very few endothelial cells were undergoing proliferation. Luteal cells stained for Ki67 in the early luteal phase (Fig. 4a) and numbers of positively staining cells had reduced significantly $(P<0.01)$ by the midluteal phase and early regression (Figs $3 c$ and $4 b, c, e$ ). During late regression (Fig. $4 \mathrm{~d}$ ) and at $36 \mathrm{~h}$ after $\mathrm{PGF}_{2 \alpha}$ (Fig. 4f), some luteal cells showed immunostaining. Other types of cell (probably leucocytes and fibroblasts based on morphology), particularly in the regression phase, showed Ki67 positive staining (Fig. 4d,f). These cells increased significantly $(P<0.01)$ on day 17 and at $36 \mathrm{~h}$ after $\mathrm{PGF}_{2 \alpha}$ administration (Fig. 3d). No immunostaining was present in negative control sections (Fig. 4f, inset). 

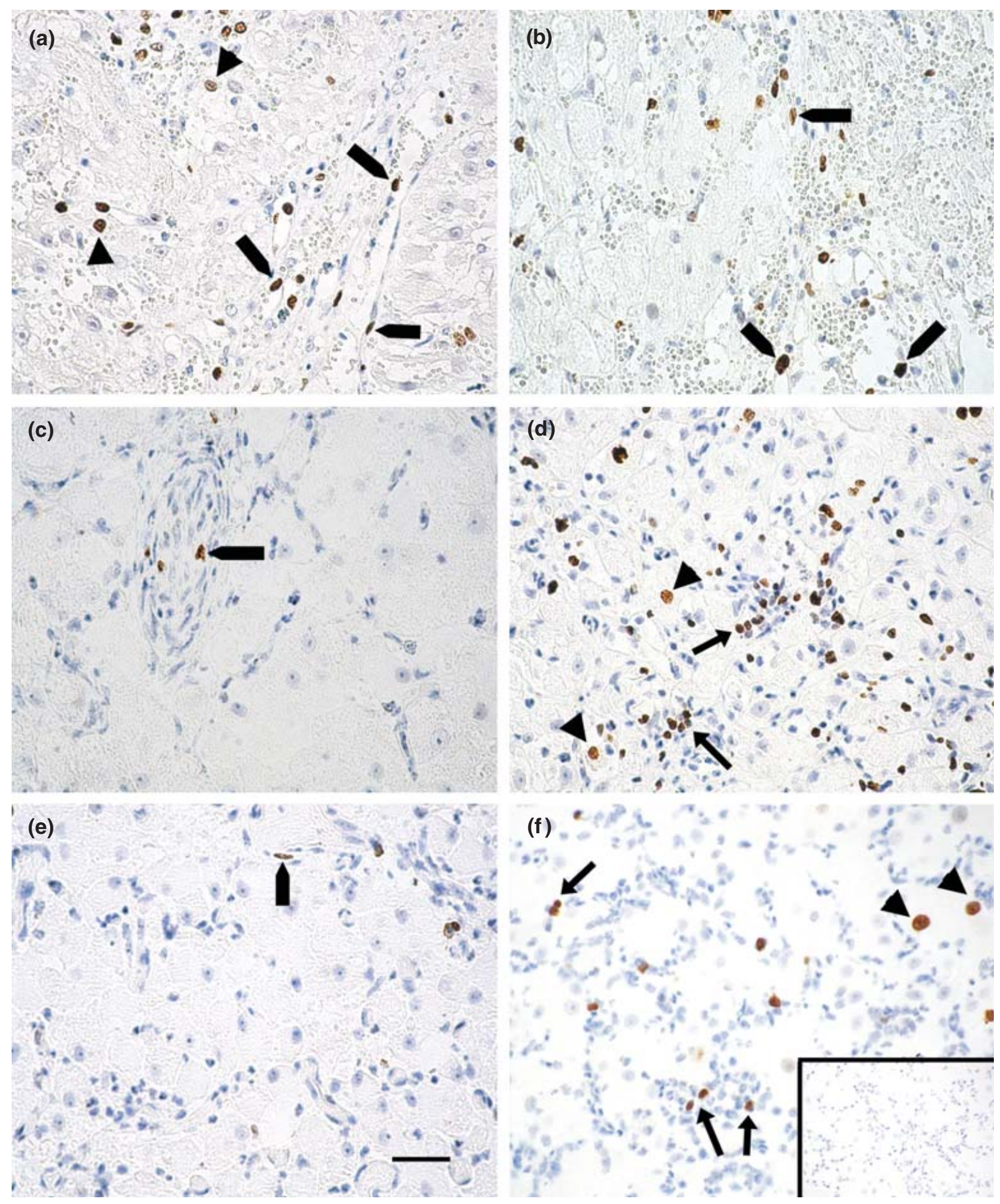

Fig. 4. Ki67 immunostaining of the equine corpus luteum during (a) the early luteal phase, days 3-4; (b) mid-luteal phase, day 10; (c) early regression, day 14 ; (d) late regression, day $17 ;$ (e) $12 \mathrm{~h}$ after prostaglandin $\mathrm{F}_{2 \alpha}\left(\mathrm{PGF}_{2 \alpha}\right.$ )-induced regression and (f) $36 \mathrm{~h}$ after $\mathrm{PGF}_{2 \alpha}$-induced regression. Inset in (f) shows a negative control section from tissue collected $36 \mathrm{~h}$ after PGF $2 \alpha$ administration, in which primary antibody was replaced by normal mouse serum. Proliferating cells show dark brown nuclear staining. Thick arrows show endothelial cells, arrowheads show luteal cells and thin arrows show inflammatory cells. Scale bar represents $25 \mu \mathrm{m}$. 

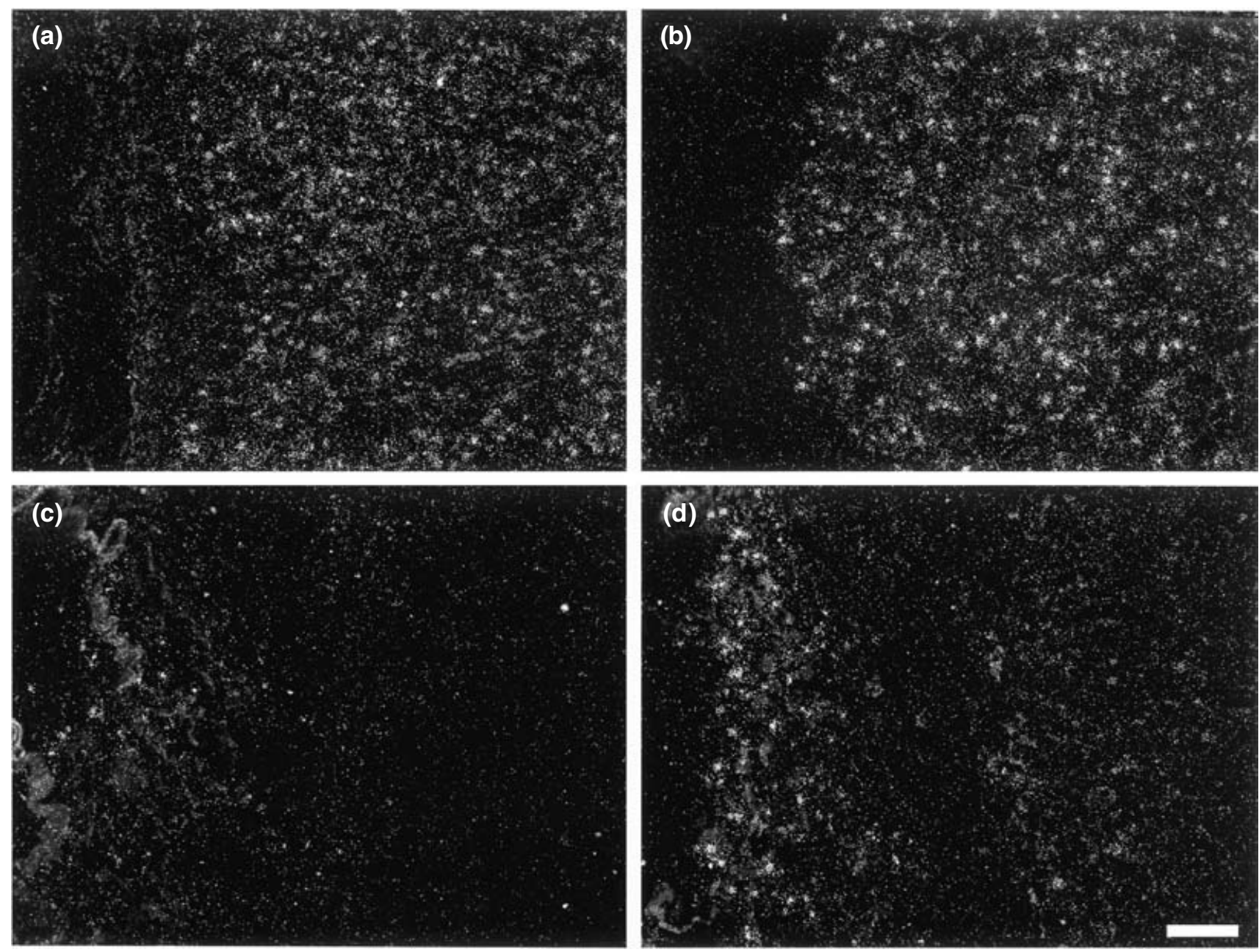

Fig. 5. In situ hybridization for vascular endothelial growth factor (VEGF) mRNA under dark field microscopy. Sections of equine corpora lutea with the cellular luteal cavity on the left-hand side are shown during (a) the early luteal phase, (b) mid-luteal phase, (c) early regression and (d) $36 \mathrm{~h}$ after $\mathrm{PGF}_{2 \alpha}$ administration during the mid-luteal phase (day 10). Cells expressing VEGF mRNA are associated with grain clusters (white grains) whereas amorphous refraction from tissue is grey. Note the large number of grain clusters in the early and mid-luteal phase with a marked reduction during early regression and $36 \mathrm{~h}$ after $\mathrm{PGF}_{2 \alpha}$ administration. In the corpora lutea shown in (c and d), the cells producing VEGF mRNA were also restricted to the peripheral or central areas of the tissue. Scale bar represents $50 \mu \mathrm{m}$.

\section{Expression of VEGF $m R N A$}

VEGF mRNA was expressed in the luteal cells and was absent from endothelial cells and neutrophils. Intense expression of VEGF mRNA was found in the luteal cells in the early (Fig. 5a) and mid-luteal phases (Figs 5b and 6a). By early and late regression, and in the $\mathrm{PGF}_{2 \alpha}$-treated animals, grain density representing VEGF mRNA in the luteal cells had decreased markedly (Fig. 5c,d; Table 1). However, as the grains decreased in the luteal cells during early regression, high VEGF mRNA expression was observed in some non-luteal cells in the cavity of the corpus luteum (Fig. 6b). These cells were identified as macrophages using MAC 387 immunostaining (Fig. 6c,d). The number of non-luteal cells expressing VEGF increased significantly $(P<0.05)$ during regression compared with the early luteal phase. Hybridization was not seen when the labelled sense RNA strand was used.

\section{VEGF immunostaining}

Immunostaining was located mainly in the cytoplasm of luteal cells. Moderate to intense immunostaining was found in most of the luteal cells during the early luteal phase (Fig. 7a). At this stage, some endothelial cells also showed positive staining. In the mid-luteal phase, strong positive staining for VEGF was observed but tended to be confined to luteal cells located adjacent to the trabeculae (Fig. 7b). By early luteal regression, only a few luteal cells showed pale immunostaining (Fig. 7c). During 
Table 1. Density of vascular endothelial growth factor (VEGF) mRNA grains in equine luteal cells and the expression of VEGF mRNA in the central cavity throughout the early luteal phase, days $3-4(n=4)$; mid-luteal phase, day $10(n=5)$; early regression, day $14(n=4)$; late regression, day $17(n=4)$; and 12 and $36 \mathrm{~h}(n=3$ each) after i.m. administration of the PGF $2 \alpha$ analogue

\begin{tabular}{|c|c|c|c|c|c|c|}
\hline Stage of the luteal phase & Days 3-4 & Day 10 & Day 14 & Day 17 & $\begin{array}{l}12 \mathrm{~h} \text { after } \mathrm{PGF}_{2 \alpha} \\
\text { administration }\end{array}$ & $\begin{array}{l}36 \mathrm{~h} \text { after } \mathrm{PGF}_{2 \mathrm{a}} \\
\text { administration }\end{array}$ \\
\hline VEGF mRNA grains in luteal cells & +++ & $++/+++$ & + & $-/+$ & $-/+$ & $-/+$ \\
\hline $\begin{array}{l}\text { Number of non-luteal cells } \\
\text { in the corpus luteum cavity } \\
\text { expressing VEGF mRNA per field }\end{array}$ & $1.6 \pm 0.4$ & $1.4 \pm 0.2$ & $6.8 \pm 1.3^{\mathrm{a}}$ & No cavity & $7.1 \pm 6.0^{\mathrm{a}}$ & $5.9 \pm 1.5^{\mathrm{a}}$ \\
\hline $\begin{array}{l}\text { Number of MAC } 387 \text { positive } \\
\text { cells in the cavity of the } \\
\text { corpus luteum per field }\end{array}$ & $1.1 \pm 0.3$ & $0.7 \pm 0.4$ & $5.3 \pm 1.4^{\mathrm{a}}$ & No cavity & $6.5 \pm 1.2^{\mathrm{a}}$ & $7.1 \pm 1.3^{\mathrm{a}}$ \\
\hline
\end{tabular}

${ }^{a}$ Significantly $(P<0.05)$ higher than early and mid-luteal phase.

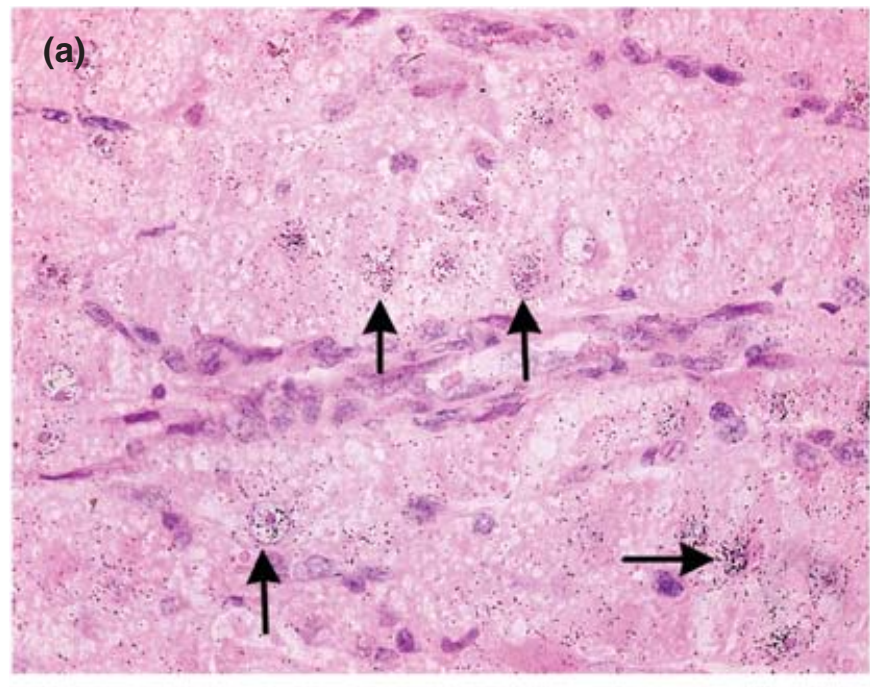

(c)

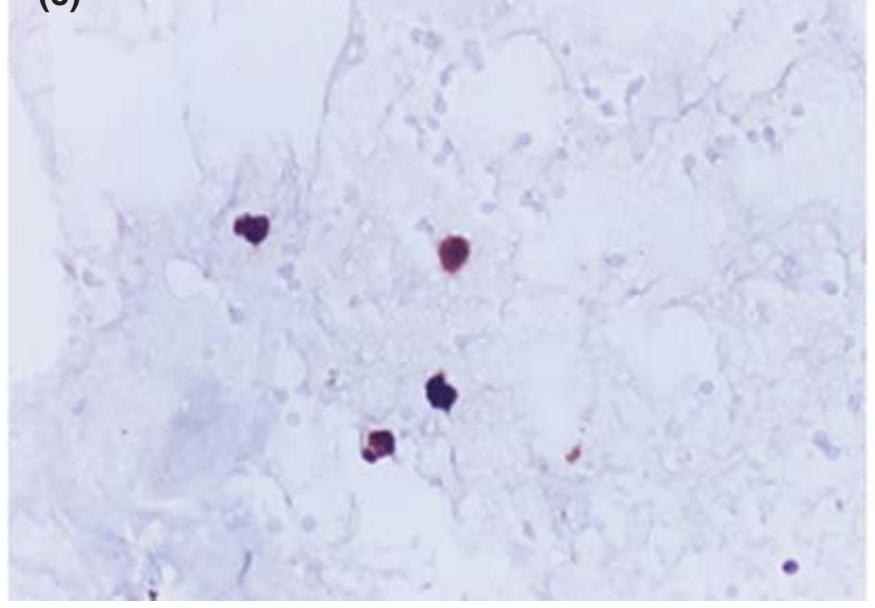

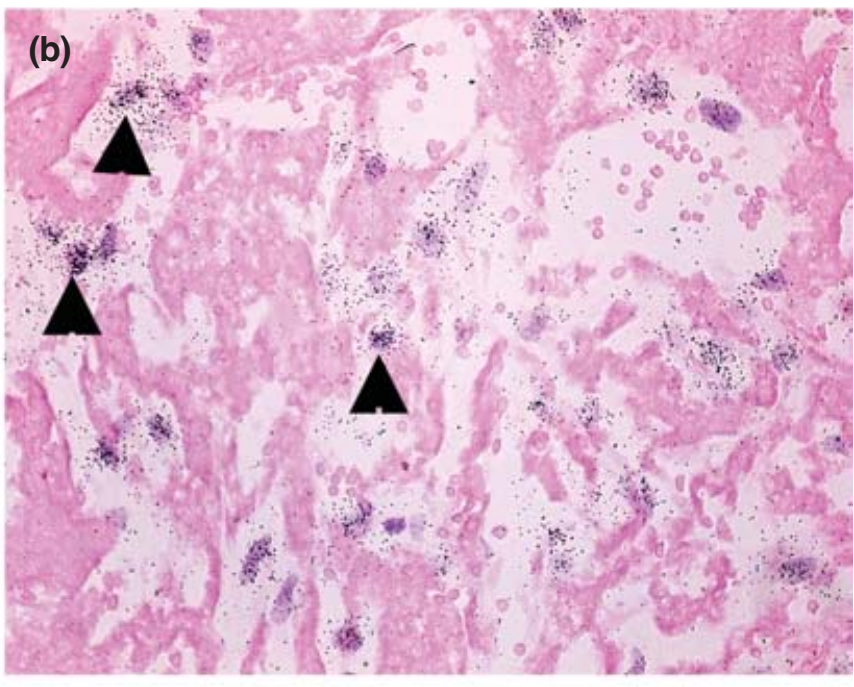

(d)

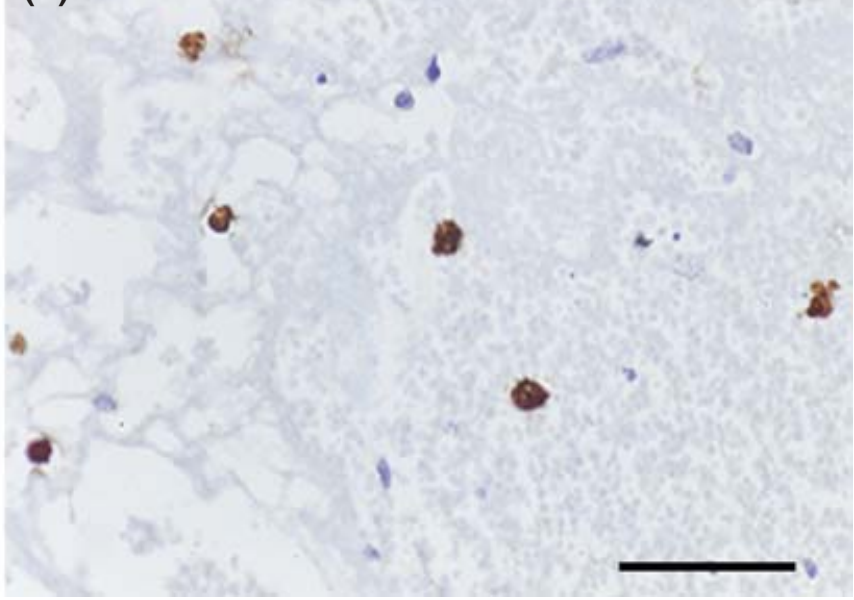

Fig. 6. In situ hybridization for vascular endothelial growth factor (VEGF) mRNA under light field microscopy for luteal and non-luteal cells, and immunostaining for MAC 387 positive cells in the equine corpus luteum. (a) A section showing VEGF mRNA counterstained with haematoxylin-eosin showing black grains representative of VEGF expression in the luteal cells in mid-luteal phase (arrows). (b) Non-luteal cells (macrophages; arrowheads) in the cavity of a corpus luteum collected $12 \mathrm{~h}$ after PGF $_{2 \alpha}$ administration expressing specific VEGF mRNA. (c) Corpus luteum cavity in the early luteal phase showing some macrophages immunostained with MAC 387. (d) Immunostaining of macrophages in the cavity of corpus luteum at early regression using MAC 387 . Scale bar represents $20 \mu \mathrm{m}$. 

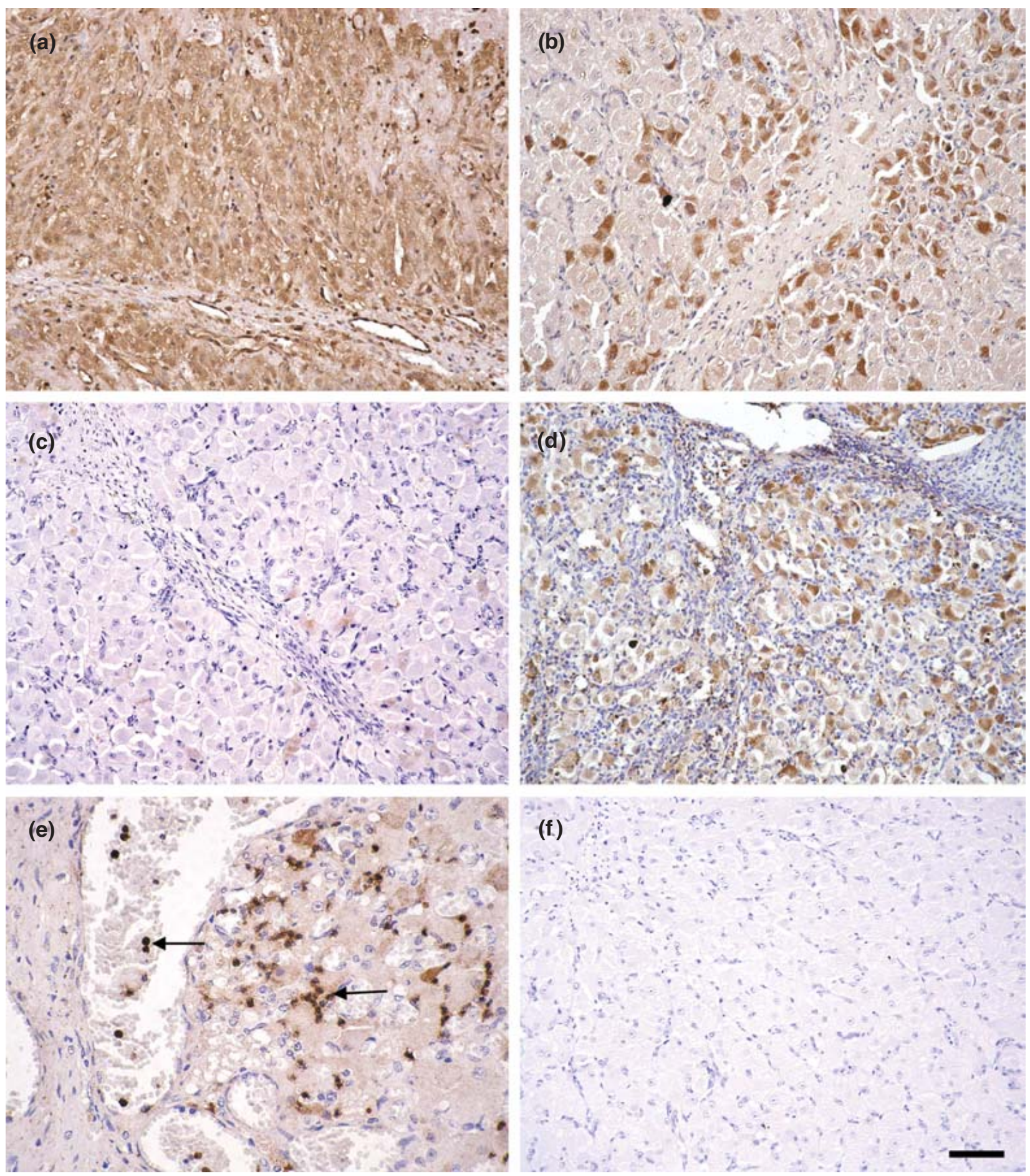

Fig. 7. Vascular endothelial growth factor (VEGF) protein immunostaining in equine corpus luteum during (a) the early luteal phase (days 3-4), (b) mid-luteal phase (day 10), (c) early regression (day 14), (d) $36 \mathrm{~h}$ after $\mathrm{PGF}_{2 \alpha}$ administration, (e) $36 \mathrm{~h}$ after PGF PG $_{2 \alpha}$ administration showing neutrophils in luteal tissue and blood vessels (arrows) and (f) negative control. Scale bar represents (a-d,f) $50 \mu \mathrm{m}$ and (e) $25 \mu \mathrm{m}$.

late regression, strong immunostaining was observed in some luteal cells scattered throughout the corpus luteum and in some sections the staining was diffuse, and the trabeculae were also stained. At 12 and $36 \mathrm{~h}$ after $\mathrm{PGF}_{2 \alpha}$ administration, some luteal cells and many neutrophils were immunostained (Fig. 7d). The neutrophils were frequently found clustered around blood vessels. Some of these vessels also contained strongly stained neutrophils 


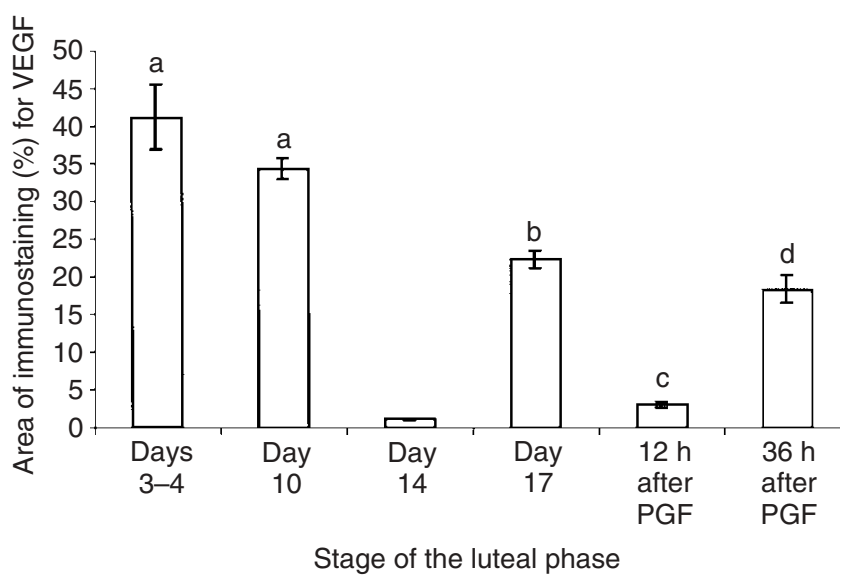

Fig. 8. The percentage area of vascular endothelial growth factor (VEGF) immunostaining in the equine corpus luteum throughout early luteal phase, days 3-4 $(n=4)$; mid-luteal phase, day 10 $(n=5)$; early regression, day $14(n=4)$; late regression, day 17 $(n=4)$; and 12 and $36 \mathrm{~h}(n=3$ each) after i.m. administration of the $\mathrm{PGF}_{2 \alpha}$ analogue. Data are expressed as mean \pm SEM. a Value significantly $(P<0.05)$ higher than all other stages; ${ }^{b}$ value significantly $(P<0.05)$ higher than early regression (day 14$)$ and $12 \mathrm{~h}$ after $\mathrm{PGF}_{2 \alpha} ;{ }^{c}$ value significantly $(P<0.05)$ higher than early regression (day 14$) ;{ }^{d}$ value significantly $(P<0.05)$ higher than early regression (day 14 ) and $12 \mathrm{~h}$ after $\mathrm{PGF}_{2 \alpha}$.

(Fig. 7e). At all stages, macrophages and other nonluteal cells showed immunostaining for VEGF both in the central cavity of the corpus luteum and in the adjacent capsule. The percentage area of immunostaining was high during the early and mid-luteal phases (Fig. 8) and then decreased significantly $(P<0.05)$ during early regression. By late regression, immunostaining increased significantly $(P<0.05)$ compared with early regression. At $12 \mathrm{~h}$ after $\mathrm{PGF}_{2 \alpha}$ administration, the immunostaining had decreased significantly $(P<0.05)$ compared with the mid-luteal phase (day 10). The area of immunostaining then increased by $36 \mathrm{~h}$ after $\mathrm{PGF}_{2 \alpha}$ administration. No immunostaining was present in the negative control sections (Fig. 7f).

\section{Discussion}

The present study describes angiogenesis and cell proliferation throughout the oestrous cycle and after $\mathrm{PGF}_{2 \alpha^{-}}$ induced luteolysis in the equine corpus luteum. The marked endothelial cell proliferation during the early and mid-luteal phases demonstrates intense angiogenesis. The high expression of VEGF mRNA and protein in the luteal cells during this period and the decrease in VEGF mRNA and reduction in endothelial cell proliferation during natural and induced luteolysis were strongly indicative of a paracrine role for VEGF in regulation of blood vessel growth and development in the corpora lutea of mares.
The high proliferation of endothelial cells in the early luteal phase led to increased vascularity as the corpus luteum matured. The presence of a dense capillary network by the mid-luteal phase is required for optimal delivery of progesterone precursors to, and progesterone from, the luteal cells, at a time when progesterone concentrations are at a maximum (Al-zi'abi et al., 2002). These findings are in agreement with reports in other species (Niswender et al., 1979; Gaytan et al., 1999; Dickson and Fraser, 2000). In the present study, a decrease in the endothelial cell proliferation during late regression, and at $36 \mathrm{~h}$ after $\mathrm{PGF}_{2 \alpha}$ administration, coincided with an observed decrease in microvessels and progesterone concentrations (Al-zi'abi et al., 2002).

VEGF stimulates increased vascular permeability, angiogenesis and endothelial cell mitosis (Folkman and Klagsburn, 1991). The peak expression of VEGF mRNA and protein during the early and mid-luteal phases in the present study showed a direct temporal association with high endothelial cell proliferation and the presence of a dense capillary network. Furthermore, the location of the protein, as visualized by immunohistochemistry, also indicated a close association with angiogenesis. In the early luteal phase, when angiogenesis was at its peak, there was diffuse immunostaining throughout the corpus luteum, including immunostaining in the endothelial cells. In the mature corpus luteum, strong immunostaining for VEGF was present in cells bordering the trabeculae where the blood vessels enter the luteal tissue. The high expression of VEGF mRNA during the mid-luteal phase is compatible with its established role in stimulating and maintaining the newly formed vasculature in the corpus luteum (Dickson et al., 2001). Inhibition of VEGF in vivo during the luteal phase in monkeys has established a physiological role for VEGF in luteal angiogenesis and function (Fraser et al., 2000). Therefore, the findings of the present study strongly indicate a role for VEGF in regulating angiogenesis in the equine corpus luteum. During early regression (day 14), VEGF mRNA expression and immunostaining decreased in the equine corpus luteum, and were associated with a marked decrease in endothelial cell proliferation. The time course of these events was also confirmed by our observations after $\mathrm{PGF}_{2 \alpha}$-induced luteolysis. At $12 \mathrm{~h}$ after $\mathrm{PGF}_{2 \alpha}$ administration, there was a sharp decrease in VEGF mRNA and protein accompanied by low endothelial cell proliferation rates. These findings indicate that either $\mathrm{PGF}_{2 \alpha}$ has a direct inhibitory effect on proliferating endothelial cells and this may coincide with the decrease in VEGF production, or that $\mathrm{PGF}_{2 \alpha}$ inhibits endothelial cell proliferation by decreasing VEGF expression.

In an earlier report, neutrophils were identified by Periodic acid-Schiff reaction and showed massive infiltration of the luteal tissue by neutrophils at 12 and $36 \mathrm{~h}$ after $\mathrm{PGF}_{2 \alpha}$ administration (Al-zi'abi et al., 2002). In the present study, many of these neutrophils showed 
positive immunostaining for VEGF protein, although mRNA encoding VEGF was not detected. This is the first report to our knowledge of VEGF protein in neutrophils in the corpus luteum. Recent studies on the human endometrium have demonstrated the presence of VEGF protein in neutrophils (Mueller et al., 2000; Gargett et al., 2001). Furthermore, stimulated neutrophils contain mRNA encoding VEGF and secrete VEGF in vitro (Scapini et al., 1999). In the present study, VEGF immunostaining in neutrophils was not associated with an increase in proliferating endothelial cells. Therefore, it is possible that after $\mathrm{PGF}_{2 \alpha}$ administration, VEGF protein may play a role in non-angiogenic functions in the corpus luteum, such as the regulation of vascular permeability, vasodilation or mediation of endothelial cell survival (Goede et al., 1998; Berisha et al., 2000). Furthermore, VEGF may play an indirect role in neutrophil migration by stimulating release of chemokines (Lee et al., 2002) that will contribute to neutrophil infiltration into the regressing corpus luteum.

Non-luteal cells, which were identified as macrophages, showed expression of VEGF mRNA and protein in the cavity of the corpus luteum throughout the luteal phase. Human macrophages can produce VEGF protein and express VEGF mRNA (Cejudo-Martin et al., 2001; Cho et al., 2001). The number of these macrophages expressing VEGF mRNA increased during regression, whereas there was a decrease in VEGF expression in luteal cells within the same corpus luteum. It is possible that macrophages trapped in the central clot experienced hypoxia which was responsible for increasing the expression of VEGF mRNA.

In late regression, there was intense immunostaining for VEGF in degenerated luteal cells. However, VEGF mRNA was absent, indicating that VEGF was not being synthesized at this time. It is possible that either VEGF is required for support of the remaining microvessels in clearing up the unwanted luteal tissue during regression, or that this staining represents the presence of residual, non-active/metabolized VEGF as suggested by Dickson and Fraser (2000) in a study that used the same antibody.

Vasodilation and infiltration by neutrophils was observed $12 \mathrm{~h}$ after $\mathrm{PGF}_{2 \alpha}$ administration. $\mathrm{PGF}_{2 \alpha}$ is generally regarded as a vasoconstrictor. Mares are particularly sensitive to the effects of administered $\mathrm{PGF}_{2 \alpha}$ (Douglas and Ginther, 1975; Oxender et al., 1975). Therefore, it is possible that the combination of the pharmacological dose of $\mathrm{PGF}_{2 \alpha}$ and the sensitivity of mares to $\mathrm{PGF}_{2 \alpha}$ resulted in this unexpected observation at the ovary.

Other types of cell with the morphology of leucocytes and fibroblasts stained positively for $\mathrm{Ki} 67$ during late regression and at $36 \mathrm{~h}$ after the administration of $\mathrm{PGF}_{2 \alpha}$. These findings support recent data, which showed increased numbers of proliferating $\mathrm{T}$ lymphocytes and macrophages during regression in the bovine corpus luteum (Petroff et al., 1997), and in the mare increased numbers of lymphocytes have been reported during both induced and natural luteal regression (Lawler et al., 1999). The role of immune cells in luteolysis has been investigated in many species, including horses (Lawler et al., 1999). Immune cells, primarily macrophages and $\mathrm{T}$ lymphocytes, are present in the corpus luteum, and their numbers increase significantly at the time of luteolysis. Invading macrophages will assist in clearing the degenerating luteal cells (Al-zi'abi et al., 2002). It has also been suggested that immune cells are involved directly in the destruction of luteal cells (Petroff et al., 1997, 1999) as well as in the loss of steroidogenic function. Fibroblasts are known to increase in number in the regressing corpus luteum in many species, including horses (Van Niekerk et al., 1975). In the present study, a proportion of cells with the morphology of luteal cells stained positive for $\mathrm{Ki67}$ during late regression and $36 \mathrm{~h}$ after $\mathrm{PGF}_{2 \alpha}$ administration. This finding was unexpected, as a number of studies in other species have demonstrated that luteal cells do not proliferate in late regression (O'Shea et al., 1986; Lei et al., 1991). In addition, this is a time of cell death in the equine corpus luteum (Al-zi'abi et al., 2002). As luteolysis is associated with both apoptosis and a form of cell death that remains to be fully defined (Al-zi'abi et al., 2002), it may be that this paradoxical labelling represents staining of degenerated protein in these dying cells.

In conclusion, luteal regression is associated with a marked decrease in proliferating endothelial cells and an increase in proliferating cells of other types, probably leucocytes and fibroblasts. The pattern of VEGF expression is strongly indicative of a paracrine role in regulation of blood vessel development, growth and regression in the equine corpus luteum. Manipulation of angiogenesis in the equine corpus luteum may provide a useful alternative method for controlling the oestrous cycle in mares.

M. O. Al-zi'abi received a fellowship from the Faculty of Veterinary Medicine, Al-Ba'ath University, Syria. The authors would like to thank $\mathrm{H}$. Wilson for carrying out the in situ hybridization for VEGF, and S. Charnock-Jones, Department of Obstetrics and Gynecology, University of Cambridge, for the gift of VEGF cDNA.

\section{References}

Al-zi'abi MO, Fraser HM and Watson ED (2002) Cell death during natural and induced luteal regression in mares Reproduction 123 67-77

Berisha B, Schams D, Kosmann M, Amselgruber W and Einspanier R (2000) Expression and tissue concentration of vascular endothelial growth factor, its receptors, and localization in the bovine corpus luteum during the estrous cycle and pregnancy Biology of Reproduction 63 11061114

Bruce NW and Moor RM (1976) Capillary blood flow to ovarian follicles, stroma and corpora lutea of anaesthetized sheep Journal of Reproduction and Fertility 46 299-304

Cejudo-Martin P, Ros J, Navasa M, Fernandez J, Fernadez-Varo G, Ruizdel-Arbol L, Rivera F, Arroyo V, Rodes J and Jimenez W (2001) Increased production of vascular endothelial growth factor in peritoneal 
macrophages of cirrhotic patients with spontaneous bacterial peritonitis Hepatology 34 487-493

Cho M, Hunt TK and Hussain MZ (2001) Hydrogen peroxide stimulates macrophage vascular endothelial growth factor release American Journal of Physiology $\mathbf{2 8 0} \mathrm{H} 2357-\mathrm{H} 2363$

Dickson SE and Fraser HM (2000) Inhibition of early luteal angiogenesis by gonadotropin-releasing hormone antagonist treatment in the primate Journal of Clinical Endocrinology and Metabolism 85 2339-2344

Dickson SE, Bicknell R and Fraser HM (2001) Mid-luteal angiogenesis and function in the primate is dependent on vascular endothelial growth factor Journal of Endocrinology 168 409-416

Douglas RH and Ginther OJ (1975) Effects of PGF P $_{2 \alpha}$ on the oestrous cycle and pregnancy in mares Journal of Reproduction and Fertility Supplement 23 257-261

Ferrara N, Chen H, Davis-Smyth T, Gerber HP, Nguyen TN, Peers D, Chisholm V, Hillan KJ and Schwall RH (1998) Vascular endothelial growth factor is essential for corpus luteum angiogenesis Nature Medicine 4 336-340

Folkman J and Klagsburn M (1991) Angiogenic factors Science 235 442-447

Fraser HM and Lunn SF (2000) Angiogenesis and its control in the female reproductive system British Medical Bulletin 56 787-797

Fraser HM, Dickson SE, Lunn SF, Wulff C, Morris KD, Carroll VA and Bicknell R (2000) Suppression of luteal angiogenesis in the primate after neutralization of vascular endothelial growth factor Endocrinology $\mathbf{4 1}$ 995-1000

Gargett CE, Lederman F, Heryanto B, Gambino LS and Rogers PA (2001) Focal vascular endothelial growth factor correlates with angiogenesis in human endometrium. Role of intravascular neutrophils Human Reproduction 16 1065-1075

Gaytan F, Morales C, Garcia-Pardo L, Reymundo C, Bellido C and Sanchez-Criado JE (1999) A quantitative study of changes in the human corpus luteum microvasculature during the menstrual cycle Biology of Reproduction 60 914-919

Goede V, Schmidt T and Kimmina S (1998) Analysis of blood vessel maturation processes during cyclic ovarian angiogenesis Laboratory Investigation 78 1385-1394

Gundersen HJG, Bendtsen TF, Korbo L et al. (1988) Some new, simple and efficient stereological methods and their use in pathological research and diagnosis Acta Pathologica, Microbiologica et Immunologica Scandinavia (APMIS) 96 379-394

Hazzard TM, Christenson LK and Stouffer RL (2000) Changes in expression of vascular endothelial growth factor and angiopoietin-1 and -2 in the macaque corpus luteum during the menstrual cycle Molecular Human Reproduction 6 993-998

Kashida S, Sugino N, Takiguchi S, Karube A, Takayama H, Yamagata Y, Nakamura Y and Kato H (2001) Regulation and role of vascular endothelial growth factor in the corpus luteum during mid-pregnancy in rats Biology of Reproduction 64 317-323

Lawler DF, Hopkins J and Watson ED (1999) Immune cell populations in the equine corpus luteum throughout the oestrous cycle and early pregnancy: an immunohistochemical and flow cytometric study Journal of Reproduction and Fertility 117 281-290

Lee TH, Avraham H, Lee SH and Avraham S (2002) Vascular endothelial growth factor modulates neutrophil transendothelial migration via upregulation of interleukin-8 in human brain microvascular endothelial cells Journal of Biological Chemistry 22 10 445-10 451

Lei ZM, Chegini N and Rao CV (1991) Quantitative cell composition of human and bovine corpora lutea from various reproductive states Biology of Reproduction 44 1148-1156
Mueller MD, Lebovic DI, Garrett E and Taylor RN (2000) Neutrophils infiltrating the endometrium express vascular endothelial growth factor: potential role in endometrial angiogenesis Fertility and Sterility $\mathbf{7 4}$ 107112

Nett TM, McClellan MC and Niswender GD (1976) Effects of prostaglandins on the ovine corpus luteum: blood flow, secretion of progesterone and morphology Biology of Reproduction 15 66-78

Neulen J, Raczek S, Pogorzelski M, Grunwald K, Yeo TK, Dvorak HF, Weich HA and Breckwoldt M (1998) Secretion of vascular endothelial growth factor/vascular permeability factor from human luteinized granulosa cells is human chorionic gonadotrophin dependent Molecular Human Reproduction 4 203-206

Niswender GD, Reimers TJ, Diekman MA and Nett TM (1976) Blood flow: a mediator of ovarian function Biology of Reproduction 14 64-81

O'Shea JD, Rodgers RJ and Wright PJ (1986) Cellular composition of the sheep corpus luteum in the mid- and late luteal phases of the oestrous cycle Journal of Reproduction and Fertility 76 685-691

Oxender WD, Noden PA, Bolenbaugh DL and Hafs HD (1975) Oestrus, ovulation and plasma hormones after $\mathrm{PGF}_{2 \alpha}$ in mares Journal of Reproduction and Fertility Supplement 23 251-255

Reynolds LP and Redmer DA (1998) Expression of the angiogenic factors, basic fibroblast growth factor and vascular endothelial growth factor, in the ovary Journal of Animal Science 76 1671-1681

Reynolds LP, Killilea SD and Redmer DA (1992) Angiogenesis in the female reproductive system Federation of American Society Experimental Biology Journal 6 886-892

Reynolds LP, Grazul-Bilska AT, Killilea SD and Redmer DA (1994) Mitogenic factors of corpora lutea Progress of Growth Factor Research 5159 175

Rodger FE, Young FM, Fraser HM and Illingworth PJ (1997) Endothelial cell proliferation follows the mid-cycle luteinizing hormone surge, but not human chorionic gonadotrophin rescue, in the human corpus luteum Human Reproduction 12 1723-1729

Scapini P, Calzetti F and Cassatella MA (1999) On the detection of neutrophil-derived vascular endothelial growth factor (VEGF) Journal of Immunological Methods 232 121-129

Sugino N, Kashida S, Takiguchi S, Karube A and Kato H (2000) Expression of vascular endothelial growth factor and its receptors in the human corpus luteum during the menstrual cycle and in early pregnancy Journal of Clinical Endocrinology Metabolism 85 3919-3924

Van Niekerk CH, Morgenthal JC and Gerneke WH (1975) Relationship between the morphology of and progesterone production by the corpus luteum of the mare Journal of Reproduction and Fertility Supplement 23 $171-175$

Wulff C, Wilson H, Largue P, Duncan WC, Armstrong DG and Fraser HM (2000) Angiogenesis in the human corpus luteum: localization and changes in angiopoietins, tie-2, and vascular endothelial growth factor messenger ribonucleic acid Journal of Clinical Endocrinology Metabolism 85 4302-4309

Zheng J, Redmer DA and Reynolds LP (1993) Vascular development and heparin-binding growth factors in the bovine corpus luteum at several stages of the estrous cycle Biology of Reproduction $491177-$ 1189

Received 8 May 2002.

First decision 23 July 2002.

Revised manuscript received 16 October 2002.

Accepted 31 October 2002. 